\title{
Gordon G. Chang, The Coming Collapse of China, New York, Random House, 2001, 344 pp.
}

Jean-François Huchet

\section{(2) OpenEdition}

\section{Journals}

\section{Electronic version}

URL: http://journals.openedition.org/chinaperspectives/364

DOI: 10.4000/chinaperspectives.364

ISSN: 1996-4617

\section{Publisher}

Centre d'étude français sur la Chine contemporaine

\section{Printed version}

Date of publication: 1 June 2003

ISSN: 2070-3449

\section{Electronic reference}

Jean-François Huchet, « Gordon G. Chang, The Coming Collapse of China, New York, Random House 2001, 344 pp. », China Perspectives [Online], 47 | May-june 2003, Online since 10 November 2006, connection on 21 September 2020. URL : http://journals.openedition.org/chinaperspectives/364 DOI : https://doi.org/10.4000/chinaperspectives.364

This text was automatically generated on 21 September 2020.

(C) All rights reserved 


\title{
Gordon G. Chang, The Coming Collapse of China, New York, Random House, 2001, 344 pp.
}

\author{
Jean-François Huchet
}

\section{EDITOR'S NOTE}

Translated from the French original by Jonathan Hall

1 This work by Gordon Chang devotes its twelve chapters to dealing with a question that has obsessed observers of political developments in China for more than twenty years: are the economic reforms not responsible for a rise in social tensions which will lead on to the implosion of the communist regime? We need to recognise that many people disillusioned by Chinese politics, especially after the 1989 massacre, have come to think that one day economics would catch up with those politics, in a sort of delayed revenge against the leadership's refusal to democratise the regime. Even if he does not spell it out clearly, Gordon Chang subscribes to this line of thought. It is a trend shared by a number of observers who have lived and worked over a long period in China, and who rightly wish to see the country develop towards democracy.

2 However, there are certain criticisms to be levelled against the central thesis of the unavoidability of a political crisis in the face sharpening economic contradictions. The question of the relationship between the economic and the political spheres is indeed relevant, but the author deals with it in a simplistic and too linear manner. Contemporary economic history offers a whole series of examples of nations where much more serious economic situations than China's have not resulted in political revolutions. When the Berlin wall fell, most of the former European socialist economies had been undergoing a deep crisis for more than fifteen years, without there being any threat to the communist regime's hold on power ${ }^{1}$. As long as there is no conflict at the top of the Party hierarchy, the repressive apparatus is able to prevent the spread of 
labour conflicts and the possibility of organised political challenge at the national level, and these are the only ways in which social discontent can be used to provoke a political crisis. The post-1989 Chinese leadership does not seem to be facing such a situation of internal division, because it has drawn the lessons of 1989 when its inner divisions were on the brink of leading to a serious political crisis. It also seems that in the face of repression, urban employees have for the moment accepted the domination of the state and the market in ordering their lives, and this increases the obstacles to developing a movement of protest and challenge at the national level ${ }^{2}$. Another regrettable shortcoming is that the author reaches his conclusions on the fall of the regime before carrying out his analysis of the economic problems, because this locks him into an excessively Manichaean view of the current reforms. His treatment of China's accession to the WTO is typical in this respect. It is true, as he asserts, that the lowering of the customs barriers will come as a shock to Chinese farmers and manufacturers. But he does not pay attention to the numerous mechanisms which will help to absorb this shock. These include China's negotiated insertion of provisions against too speedy liberalisation (such as the power to increase agricultural subsidies, and the imposition of quotas on grain imports fixed at $10 \%$ of domestic consumption), or the adoption of protectionist strategies other than customs measures, in which China is actually at one with the major trading powers (for example, in the use of health and safety provisions, delaying tactics in the settlement of disputes, and regional protectionism). Similarly, despite the importance of the problems confronting the banking sector, which the author emphasises, China still retains the means for preventing a collapse like the one in Argentina. This ability comes down to the fact that the risk to which the banks are exposed in China is assumed by the sovereign state, since with the sole exception of the Mingsheng Bank, the banking sector is under state control, with a very low level of foreign debt and very limited control over capital by foreign investors. If depositors start to panic, the state can always resort to force and block withdrawals from savings accounts. To sum up, a more careful analysis of the three interlocking sides of the triangle (economic problems, social consequences, and repercussions for the political structure) would have allowed the author to reach quite opposite conclusions, namely that there is at present in China no conjunction of factors which could see the economic contradictions leading to a serious political crisis.

3 However, I do not believe that this book should be dismissed, or relegated to the heaps of those worthless writings on China which start from a preconceived view and rely on fashionable ideas, whether positive or negative, about the country's future. Even if this work's conclusions are mistaken in the light of the current political situation, it still conveys a valuable reminder of the weaknesses in the so-called "Chinese economic miracle" and of its areas of potential breakdown if the political situation should change. These include environmental issues, the endemic corruption, the regime's difficulties in controlling information, the barely contained bankruptcy, the increasing social inequality, the rising unemployment, and the hazards involved in reforming the public enterprises. The social situation is potentially more explosive than it was in 1989; hence the current powerholders' extreme wariness whenever there are signs of incipient organised social movements. The author is also very persuasive in showing that these problems have become largely interconnected. The Chinese government can no longer rely, as it could in the 1980s and early 1990s, on what could be called damage control measures, meaning that particular social issues could be settled one at a time, while the reforms could be continued in another area of the economy without causing 
worries over the interconnections. Gordon Chang is right to insist that nowadays the Chinese government has to mount a concerted global attack on a range of problems that can no longer be so easily separated. What is at stake now may well be the ability of the government to carry on reforming on a step-by-step basis, as opposed to adopting a "shock therapy" strategy. One possible scenario might well be the regime's inability to reform itself in order to respond to challenges which could lead to its collapse. Nonetheless, the author could have explored the other ways open to the Party for dealing with the need for gradual institutional and political changes, thus allowing it to remain in power and continue with its more or less successful containment of the enormous contradictions confronting it.

4 In conclusion, then, despite its too simple central thesis, this book is to be recommended, if only to alert the reader to the economic challenges which will confront China over the next decade.

\section{NOTES}

1. Jeffrey Kopstein, The Politics of Decline in East Germany, 1945-1989, Chapel Hill, University of North Carolina Press, 1997, 246 pp.

2. Marc J. Blecher, "Hegemony and Workers' Politics in China", in The China Quarterly, No. 170, June 2002, pp. 283-303. 